\title{
Evaluation of the Work Ability of workers in the furniture sector of a city in the south of Brazil
}

\section{Avaliação da Capacidade para o Trabalho de trabalhadores do setor moveleiro de uma cidade no sul do Brasil}

\author{
João Eduardo Linhares ${ }^{1}$ (1) \\ Jaqueline Marcis' ${ }^{1}$ (1) \\ Renato Tonello' ${ }^{1}$ (1) \\ Sergio Luiz Ribas Pessa' \\ Gilson Adamczuk Oliveira ${ }^{1}$
}

\begin{abstract}
How to cite: Linhares, J. E., Marcis, J., Tonello, R., Pessa, S. L. R., \& Oliveira, G. A. (2019). Evaluation of the Work Ability of workers in the furniture sector of a city in the south of Brazil. Gestão \& Produção, 26(3), e3619. https://doi.org/10.1590/0104-530X3619-19
\end{abstract}

\begin{abstract}
The aging of the workforce is a phenomenon that the world population is facing. Researchers at the Finnish Institute of Occupational Health have developed a tool for assessing the work ability, an instrument through which it is possible to identify the existence of early functional aging among a certain group of workers. The present study measured the Work Capability Index (WAI) of workers from 5 small furniture companies in a city in southern Brazil. It was possible to notice that with the increase of age, the average WAI of the workers was smaller, although there was no statistical significance ( $p>0.05$ ), by the nonparametric Kruskal-Wallis test. The variables "civil status", "current schooling" and "education" presented statistical significance $(\mathrm{p}<0.05)$, being possible to associate these variables with the decline in work ability. The results showed that only $13.6 \%$ of workers have a low or moderate work ability. For $86.4 \%$, the results showed good or excellent indices, and in these cases, actions must be taken that can maintain and improve the work ability.
\end{abstract}

Keywords: Work ability; Aging; Furniture sector.

Resumo: $O$ envelhecimento da força de trabalho é um fenômeno que a população mundial está enfrentando. Pesquisadores do Instituto Finlandês de Saúde Ocupacional desenvolveram uma ferramenta de avaliação da capacidade para o trabalho, instrumento por meio do qual é possivel identificar a existência de um envelhecimento funcional precoce dentre um determinado grupo de trabalhadores. O presente estudo mensurou o Índice de Capacidade para o Trabalho (ICT) de trabalhadores de 5 pequenas empresas do setor moveleiro, em um uma cidade do sul do Brasil. Foi possivel notar que com o aumento da idade, o ICT médio dos trabalhadores foi menor, embora não houve significância estatística ( $p>0,05)$, pelo teste não paramétrico de Kruskal-Wallis. As variáveis "estado civil", "estuda atualmente" "e "escolaridade" apresentaram significância estatística $(p<0,05)$, sendo possivel associar estas variáveis ao declínio da capacidade para o trabalho. Os resultados revelaram que apenas 13,6\% dos trabalhadores possuem baixa ou moderada capacidade para o trabalho. Para $86,4 \%$ os resultados revelaram índices bons ou ótimos, sendo que nestes casos devem ser realizadas ações que possam manter e melhorar a capacidade para o trabalho.

Palavras-chave: Capacidade para o trabalho; Envelhecimento; Setor moveleiro.

\section{Introduction}

The aging of the workforce is a phenomenon that many countries have gone through or are going through. According to the World Health Organization (WHO), the world population over the age of 60 will almost double, from $12 \%$ to $22 \%$ between 2015 and 2050. In countries like Brazil, China and India, the

population over 60 years old will increase from $10 \%$ to $20 \%$ in a little more than 20 years (WHO, 2015; Martinez \& Latorre, 2008).

Before the retirement age is reached, workers in the market may seek to improve their quality of life and their work ability. Companies and governments

\footnotetext{
${ }^{1}$ Programa de Pós-graduação em Engenharia de Produção e Sistemas, Universidade Tecnológica Federal do Paraná - UTFPR, Via do Conhecimento, Km 1, CEP 85503-390, Pato Branco, PR, Brasil, e-mail: jelinhares@gmail.com
}

Received Nov. 21, 2016 - Accepted Aug. 1, 2017

Financial support: None. 
can also promote policies to promote the work ability, as indicated by previous studies (Tuomi et al., 2001; Tuomi et al., 2005; Martinez et al., 2010; Koolhaas et al., 2014).

The concern with functional aging should be understood as a factor influencing the most varied branches of activities. In Brazil, a country of great territorial extension, the economy is driven by the most varied fields of work, including the furniture industry. According to the Ministry of Development, Industry and Foreign Trade (Brasil, 2016), the furniture production chain is among the most important in the manufacturing industry in the country, especially for its potential to generate jobs.

The furniture sector had its development from the 1950s onwards, and its consolidation took place between 1960 and 1970. The three regions that are most prominent in this industrial sphere are the city of São Paulo and the states of Rio Grande do Sul and Santa Catarina (Brasil, 2016). The Federation of Industries of the State of Santa Catarina (FIESC), in an annual publication on the economy of Santa Catarina (SC), highlights that there are about 2,719 companies and 29,700 workers in the state. The sector accounts for $2.0 \%$ of the value of industrial processing and $2.3 \%$ of exports in the state economy. The western region is the second largest manufacturing center of $\mathrm{SC}$, thus revealing the importance of carrying out the study in this region (FIESC, 2015).

Also, the FIESC study shows that $20.6 \%$ of the state's jobs in the industry are generated by microenterprises, and another $24.5 \%$ by small companies. This data highlights the relevance of these classes of companies, as companies of these sizes significantly represent the industrial population of Santa Catarina.

Therefore, in view of this scenario, the present study had the objective of analyzing the work ability when faced with the functional aging of furniture workers, while also evaluating the sociodemographic profile and its influence on the Work Ability Index (WAI).

\section{Literature review}

To investigate the existence of functional aging, Finnish researchers developed an instrument to assess the worker's ability to perform his or her activities. This tool is called the Work Ability Index (WAI) (Tuomi et al., 2005; Ilmarinen et al., 1997).

Studies have shown that over the years, the work ability decreases, causing an imbalance between the worker's skills and the demands of the job. Thus, in some cases, the ability of the individual decreases faster than the demand, depending on the demands of work, health status and physical and mental abilities of the worker. This scenario can lead to early functional aging. In Brazil, studies indicate that the concern with early functional aging should begin at 45 years of age (Fischer et al., 2005; Martinez \& Latorre, 2006; Amorim et al., 2014).

The work ability is understood by how well the worker currently is or will be in the near future and how much he is able to perform his work, based on his abilities, state of health and the demands of the work (Tuomi et al., 2005).

As necessary as measuring the work ability is implementing actions that promote the maintenance and improvement of this ability. Improvement of working conditions in organization and environment, promotion of workers' health and individual resources and skills are actions favorable to increasing or restoring the individual's ability. Moreover, the cost of actions to promote the work ability is usually lower when compared to the cost of health treatments or accidents (Martinez et al., 2010).

Promoting these actions to the workers, especially the older ones, helps the individual to feel competent and capable. And in each area of the organization it is possible to take different measures, such as improving work postures; clear and objective identification of tasks; guidance on health, physical activities or artistic hobbies; encouraging the development of skills, competencies and professional training (Tuomi et al., 2001).

In addition to analyzing the work ability in the individuals who are actively performing their functions, it is necessary to investigate aspects of their social life that may influence the performance of their work (Ilmarinen et al., 1997; Kumashiro, 2014; Larsson et al., 2012; Martinez et al., 2009; Saltychev et al., 2013).

Lifestyle, translated as practices and habits such as smoking, alcohol consumption and obesity can influence the reduction of the work ability. On the other hand, physical exercise is generally associated with good work ability (Martinez et al., 2010).

\section{Methodology}

This research has characteristics of a descriptive survey, with transversal data collection, and non-probability sampling for convenience. Continuous quantitative data collection was performed (Freitas et al., 2000).

The ability to carry out activities in the company was evaluated through the Work Ability Index (WAI) questionnaire developed by the Finnish Occupational Health Institute (FIOH) in the 1980s (Martinez et al., 2010; El Fassi et al., 2013). This method has been translated into 26 languages since 1993, becoming a globally applied method (Ilmarinen, 2009).

The WAI is a self-administered questionnaire whose results are from the opinion of the workers themselves. The instrument was developed addressing 7 constructs, in which the worker gives his opinion about his ability to perform the current work compared to the best in his life, work ability in relation to the 
demands of the job, current number of diseases diagnosed by doctor, missed work due to sickness during the last year (absenteeism), self-prognosis of work ability in two years, and mental resources (Monteiro et al., 2005; Huuhtanen et al., 1997).

From the answers, the index is calculated, which can be categorized as follows: low work ability score from 7 to 27 ; moderate ability - score from 28 to 36; good ability - score from 37 to 43; and optimal ability - score 44 to 49 (Tuomi et al., 2005; Padula et al., 2013). The application of WAI is adequate to promote diagnoses of health and the potential of the individual's work ability (Tuomi et al., 1997).

In addition to approaching the above constructs, sociodemographic data was also collected, aiming to investigate the influence of the individual's social life on the work.

Data collection was carried out in a small municipality of southern Brazil, in the state of Santa Catarina, with a sample of 51 workers, of which eight were from the administrative sector and 43 were from the production sector. The sample was obtained from eight micro and small companies of the furniture industry. All guest workers accepted to participate in the survey, resulting in a participation rate of $100 \%$.

The questionnaires were applied in the work places, and two forms were used. The first one was through the application of questionnaires to the entire group of employees of the company, and the researcher was present to clear up any doubts the interviewees might have had. This methodology was used in 5 companies. In another 3 companies, at the request of the management, the questionnaires were applied individually in order not to stop the production of the company. In this case, the workers went to an office and answered the questions directly to the researcher, who filled out the forms.

The analysis of the data was carried out using a descriptive statistical approach. The normality of the data was tested using the Shapiro-Wilk K tests $(\mathrm{p}<0.05)$, rejecting the null hypothesis that the data comes from a normal distribution.

Since the data is not normal, violating one of the hypotheses to use Analysis of Variance (ANOVA), the data was evaluated from the medians using the Kruskal-Wallis non-parametric test. It was investigated whether there was statistical significance between the dependent variable (WAI) and the influence factors.

\section{Results}

\subsection{Sociodemographic profile analysis}

Among the 51 workers interviewed, $90.2 \%$ are male and $9.8 \%$ are female; the average age was 32.16 years and standard deviation $\mathrm{s}=12.01$. For the purposes of analysis, the workers were separated into groups, administrative with eight employees and production with 43. Table 1 presents the sociodemographic characteristics of the groups:

The study population was predominantly male in the production sectors of the companies $(97.67 \%)$. In the administrative sectors there was a balance between the participants (50\%). About $75 \%$ of workers were under 40 years old, with an average age of 32.16 years. This result was also found with carpenters from a city of Mineira, whose average age

Table 1. Sociodemographic data of workers.

\begin{tabular}{|c|c|c|c|c|c|}
\hline \multicolumn{2}{|r|}{ Variables } & \multicolumn{2}{|c|}{$\begin{array}{c}\text { Administrative Group } \\
\qquad(N=8)\end{array}$} & \multicolumn{2}{|c|}{$\begin{array}{c}\text { Production Group } \\
(N=43)\end{array}$} \\
\hline & & $\%$ & (N) & $\%$ & $(\mathrm{~N})$ \\
\hline \multirow{3}{*}{ Gender } & Female & 50.00 & 4 & 2.33 & 1 \\
\hline & Male & 50.00 & 4 & 97.67 & 42 \\
\hline & Single & 62.50 & 5 & 30.23 & 13 \\
\hline \multirow[t]{3}{*}{ Civil Status } & Separated/Divorced/Widowed & 12.50 & 1 & 4.65 & 2 \\
\hline & Married; Lives with partner. & 25.00 & 2 & 65.12 & 28 \\
\hline & Elementary School & 12.50 & 1 & 41.86 & 18 \\
\hline \multirow{3}{*}{ Education } & High School & 12.50 & 1 & 51.16 & 22 \\
\hline & College Education & 50.00 & 4 & 6.98 & 3 \\
\hline & Graduate Education & 25.00 & 2 & - & - \\
\hline \multirow{4}{*}{ Family Income } & Up to $R \$ 1,760.00$ (2 Minimum Wages) & 25.00 & 2 & 16.28 & 7 \\
\hline & $\begin{array}{l}\text { From } R \$ 1,761.00 \text { to } R \$ 3,520.00 \\
\text { (from } 2 \text { to } 4 \mathrm{MW} \text { ) }\end{array}$ & 75.00 & 6 & 55.81 & 24 \\
\hline & $\begin{array}{l}\text { From } R \$ 3,521.00 \text { to } R \$ 5,280.00 \\
\text { (from } 4 \text { to } 6 \mathrm{MW} \text { ) }\end{array}$ & - & - & 13.95 & 6 \\
\hline & Over $\mathrm{R} \$ 5,281.00$ (more than $8 \mathrm{MW}$ ) & - & - & 4.65 & 2 \\
\hline \multirow{2}{*}{ Work Demands } & Mental & 100.00 & 8 & - & - \\
\hline & Both mental and physical & - & - & 100.00 & 43 \\
\hline
\end{tabular}


was 33.8 years (Silva et al., 2002), and in a study with carpenters from the Federal District, their average age was 31.5 years (Fiedler et al., 2001).

\subsection{Analysis of work ability in relation to age}

The average WAI of the workers was $41.81(\mathrm{~s}=4.78)$, ranging from 26 (low work ability) to 48 (excellent work ability). The results of the WAI were obtained from the 7 constructs, as shown in Table 2:

Figure 1 shows the distribution of the indices obtained, taking into account the WAI on the y-axis, and the age on the $\mathrm{x}$-axis. In addition, horizontal lines were drawn to divide the WAI categories, and a horizontal line at the age " 45 years":

As can be seen in Figure 1, there was only 1 worker in the category WAI Low. Still, using a vertical line at age " 45 years", it can be observed that the population in analysis presents two workers with a low or moderate WAI level, while eight other workers are in the good and excellent categories. It was possible to verify that seven workers had indices in the classification of low or moderate work ability. Individuals age 45 years or older represent $13.72 \%$ of the total sample.
In addition to observing WAI by age, the elements of the population were divided between workers in the administrative and production groups. Taking into account these sectors, there was no statistical significance between the groups, since $\mathrm{p}>0.05$. Table 3 shows the number of workers in each WAI classification:

The fact that there is no statistical significance between the groups may be related to the size of the sample, and, respectively, of the groups. As there is a disparity between the number of members of the administrative and production groups, it is not possible to afirm that the work ability can be greater in one group or another. However, the literature points out that workers with physical overload are more susceptible to reduced work ability (Chan et al., 2000; Huuhtanen et al., 1997; Klasan et al., 2013).

Of the population investigated, nine participants were 45 years of age or older - $17.64 \%$ of the total. Among these workers, the presence of two older workers was highlighted, one being 61 years old and the other being 68 years old. The concern with functional aging, which in Brazil should become significant after 45 years of age (Fischer et al., 2005), is important in the context studied. Although there

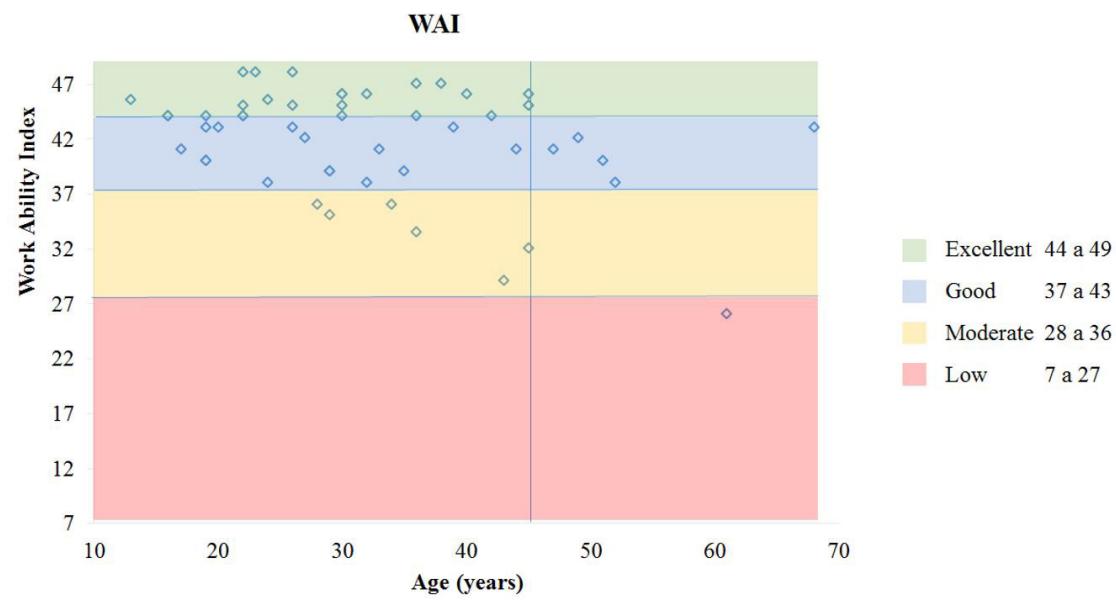

Figure 1. Scatter Chart of the Work Ability Index in relation to the age of the workers. Source: survey data (2016).

Table 2. WAI values obtained from the 7 constructs of the instrument.

\begin{tabular}{lccccccc}
\hline \multicolumn{1}{c}{ Construct } & $\boldsymbol{N}$ & Average & Median & $\begin{array}{c}\text { Standard } \\
\text { Deviation }\end{array}$ & $\begin{array}{c}\text { Coef. of } \\
\text { Variation } \\
\text { \% }\end{array}$ & Min. & Max. \\
\hline Current work ability & 51 & 7.88 & 8 & 1.53 & 19.43 & 1 & 10 \\
Physical and mental demands & 51 & 7.71 & 8 & 1.30 & 16.86 & 4 & 10 \\
Diagnosed diseases & 51 & 6.27 & 7 & 1.52 & 24.29 & 1 & 7 \\
Inability to work & 51 & 5.39 & 6 & 1.17 & 21.65 & 1 & 6 \\
Absenteeism & 51 & 4.47 & 5 & 0.83 & 18.64 & 1 & 5 \\
Self prognosis & 51 & 6.29 & 7 & 1.65 & 26.26 & 1 & 7 \\
Mental resources & 51 & 3.78 & 4 & 0.41 & 10.98 & 3 & 4 \\
Index - WAI & $\mathbf{5 1}$ & $\mathbf{4 1 . 8 1}$ & $\mathbf{4 3}$ & $\mathbf{4 . 7 8}$ & $\mathbf{1 1 . 4 3}$ & $\mathbf{2 6}$ & $\mathbf{4 8}$ \\
\hline
\end{tabular}

Source: survey data (2016). 
was no statistical significance of age influencing this population, previous studies have shown that age is a factor of influence, and that with the increase of age, work ability tends to reduce (Chan et al., 2000; Kumashiro, 2014; Ilmarinen et al., 1997; Monteiro et al., 2005).

When classifying workers into age groups, there was no statistical significance between classes ( $p>0.5$ ). In Figure 2, it is possible to verify the WAI averages and the variation range of the indices of each age group:

Using the Least Square Difference - LSD intervals of Fisher 's method as a discriminant method, it was possible to identify two homogeneous groups: the first one consisted of the workers of older age groups who present a lower WAI average; and the second was made up of workers of younger age groups with higher WAI averages. The LSD intervals still indicate that workers in the age group 40 to 49 can be in both group 1 and group 2. However, considering that the

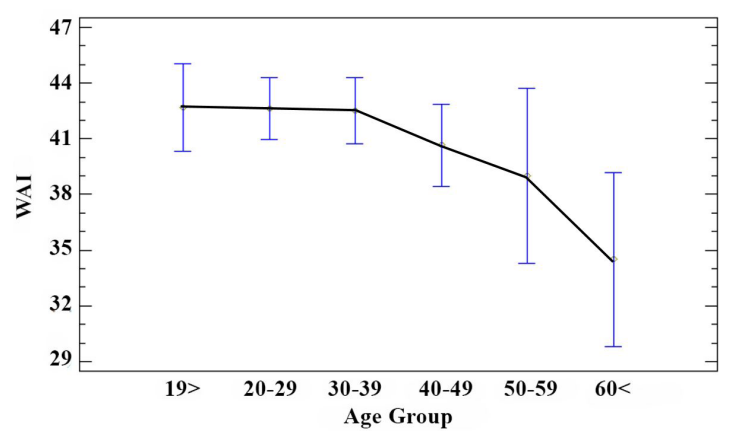

Figure 2. Graph of averages and intervals of WAI against age group. Source: survey data (2016). literature indicates that there is a greater decline in the work ability starting from 45 years of age, it is possible to include the age group 40-49 together with group 1. Table 4 shows the results, corroborating the perception of WAI decline with the increase of age:

It is important to note that there was no statistical significance between WAI and age group. The workers age 40-49 and 50-59 are in a transition phase, where it can be observed that there is a tendency of WAI reduction with advancing age. Since homogeneous group 1 shows indications of declining work ability due to age, it was considered important to analyze workers in this group in more detail. Table 5 presents the results obtained from the WAI from the constructs of the instrument, classified by the age group:

When evaluating the results of the three age groups of older workers (40-49, 50-59 and 60 or more), it is possible to verify that in the construct "Current Work Ability," as the age group increased, the construct index reduced, indicating that with increasing age, individuals feel less able to work. A similar situation is repeated in the constructs "Diagnosed diseases" and "Inability to work", which can be identified as the main factors that cause less ability in older workers.

Once again, it stands out that although the data presented this tendency, it was not possible to prove this statistically. However, a lower work ability with advancing age can be easily found in the literature (Fischer et al., 2005; Ilmarinen et al., 1997; Tuomi et al., 1997).

The results indicate the average time that the individuals work for the company is 4.39 years $(\mathrm{s}=3.71)$, while the average time working in their particular job position reaches 9.65 years $(\mathrm{s}=10.67)$.

Table 3. Classification of the Work Ability Index according to the work sectors.

\begin{tabular}{|c|c|c|c|c|c|}
\hline \multirow{2}{*}{ Work Ability } & \multirow{2}{*}{ Score } & \multicolumn{2}{|c|}{ Administrative Group $(N=8)$} & \multicolumn{2}{|c|}{ Production Group (N=43) } \\
\hline & & $\%$ & $(\mathbf{N})$ & $\%$ & $(\mathbf{N})$ \\
\hline Low & $7-27$ & - & 0 & 2.33 & 1 \\
\hline Moderate & $28-36$ & 12.50 & 1 & 11.53 & 5 \\
\hline Good & $37-43$ & 12.50 & 1 & 32.56 & 14 \\
\hline Excellent & $44-49$ & 75.00 & 6 & 53.49 & 23 \\
\hline Total & - & 100.00 & 8 & 100.00 & 43 \\
\hline
\end{tabular}

Source: survey data (2016).

Table 4. Homogeneous groups of age groups against the WAI index obtained.

\begin{tabular}{cccc}
\hline Age Group & N & WAI Average & Homogeneous Group \\
\hline $60<$ & 2 & 34.5 & 1 \\
$50-59$ & 2 & 39.0 & 2 \\
$40-49$ & 9 & 40.7 & \\
$30-39$ & 14 & 42.5 & \\
$20-29$ & 16 & 42.7 & \\
$19>$ & 8 & 42.7 & \\
\hline
\end{tabular}

Source: survey data (2016). 
These factors did not represent statistical significance, being $\mathrm{p}>0.05$.

By investigating the time worked in the work position, using the Multiple Range Tests, and discriminating the LSD intervals of the Fisher method, it was possible to classify the workers into three homogeneous groups. Those categorized with good WAI work less time in their position $(\mathrm{s}=6.42)$, forming the first group. In the second group, the employees were classified with good WAI ( $\mathrm{s}=12.87)$ and with moderate work ability $(\mathrm{s}=12,15)$ and had a longer average time in their job position. Finally, in the third group is the only worker with low work ability, with 40 years in his position. Table 6 shows this classification:

Regarding working time in the job position, there was no statistical difference, but it stands out that in the research universe, 10 workers (about $20 \%$ of the universe) affirmed to performing their function for more than 20 years (reaching up to 40 years). This fact may indicate that although age may influence the worker's ability, professional satisfaction and fulfillment can also be an attenuating factor. Another fact that may have influenced these individuals is that 4 of them reported to occupy the position of carpentry manager. These investigations may be subject to future studies. However, this phenomenon, also proven by the literature, shows that workers over the years find it difficult to perform their job well. Whether it is because of a decline in cognitive ability, a reduction in physical capacity, or even the presence of illnesses, it is a fact that workers do not have the same work ability with the passing of time.

Table 5. Index of WAI constructs for the age groups of workers age 40 or over.

\begin{tabular}{|c|c|c|c|c|c|c|c|c|}
\hline Construct & $\begin{array}{c}\text { Age } \\
\text { Group }\end{array}$ & $N$ & Median & Average & $\begin{array}{l}\text { Standard } \\
\text { Deviation }\end{array}$ & $\begin{array}{c}\text { Coefficient of } \\
\text { Variation \% }\end{array}$ & Min. & $\operatorname{Max}$. \\
\hline \multirow{3}{*}{$\begin{array}{l}\text { Current work ability } \\
(0 \text { to } 10)\end{array}$} & $40-49$ & 9 & 8.0 & 7.56 & 1.24 & 16.36 & 5 & 9 \\
\hline & $50-59$ & 2 & 7.5 & 7.50 & 0.71 & 9.43 & 7 & 8 \\
\hline & $60<$ & 2 & 6.5 & 6.50 & 2.12 & 32.64 & 5 & 8 \\
\hline \multirow{3}{*}{$\begin{array}{l}\text { Physical and mental demands } \\
\text { ( } 2 \text { to } 10)\end{array}$} & $40-49$ & 9 & 8.0 & 7.44 & 1.94 & 26.11 & 4 & 10 \\
\hline & $50-59$ & 2 & 7.5 & 7.50 & 0.71 & 9.43 & 7 & 8 \\
\hline & $60<$ & 2 & 7.5 & 7.50 & 0.71 & 9.43 & 7 & 8 \\
\hline \multirow{3}{*}{$\begin{array}{l}\text { Diagnosed diseases } \\
\text { (1 to } 7)\end{array}$} & $40-49$ & 9 & 7.0 & 5.78 & 2.44 & 42.20 & 1 & 7 \\
\hline & $50-59$ & 2 & 3.5 & 3.50 & 0.71 & 20.20 & 3 & 4 \\
\hline & $60<$ & 2 & 4.0 & 4.00 & 1.42 & 35.35 & 3 & 5 \\
\hline \multirow{3}{*}{$\begin{array}{l}\text { Inability to work } \\
\text { (1 to } 6)\end{array}$} & $40-49$ & 9 & 6.0 & 5.33 & 0.87 & 16.24 & 4 & 6 \\
\hline & $50-59$ & 2 & 5.0 & 5.00 & 0.00 & 0.00 & 5 & 5 \\
\hline & $60<$ & 2 & 4.5 & 4.50 & 2.12 & 47.14 & 3 & 6 \\
\hline \multirow{3}{*}{$\begin{array}{l}\text { Absenteeism } \\
(1 \text { to } 5)\end{array}$} & $40-49$ & 9 & 4.0 & 4.11 & 1.05 & 25.64 & 2 & 5 \\
\hline & $50-59$ & 2 & 4.5 & 4.50 & 0.71 & 15.71 & 4 & 5 \\
\hline & $60<$ & 2 & 4.0 & 4.00 & 1.41 & 35.35 & 3 & 5 \\
\hline \multirow{3}{*}{$\begin{array}{l}\text { Self prognosis } \\
(1,4 \text { or } 7)\end{array}$} & $40-49$ & 9 & 7.0 & 6.67 & 1.00 & 15.00 & 4 & 7 \\
\hline & $50-59$ & 2 & 7.0 & 7.00 & 0.00 & 0.00 & 7 & 7 \\
\hline & $60<$ & 2 & 4.0 & 4.00 & 4.24 & 106.06 & 1 & 7 \\
\hline \multirow{3}{*}{$\begin{array}{l}\text { Mental resources } \\
(1 \text { to } 4)\end{array}$} & $40-49$ & 9 & 4.0 & 3.78 & 0.44 & 11.67 & 3 & 4 \\
\hline & $50-59$ & 2 & 4.0 & 4.00 & 0.00 & 0.00 & 4 & 4 \\
\hline & $60<$ & 2 & 4.0 & 4.00 & 0.00 & 0.00 & 4 & 4 \\
\hline \multirow[t]{4}{*}{ Index - WAI } & $40-49$ & 9 & 42.0 & 40.67 & 6.12 & 15.06 & 29 & 46 \\
\hline & $50-59$ & 2 & 39.0 & 39.00 & 1.41 & 3.63 & 38 & 40 \\
\hline & $60<$ & 2 & 34.5 & 34.50 & 12.02 & 34.84 & 26 & 43 \\
\hline & Total & 51 & 43.0 & 41.81 & 4.78 & 11.43 & 26 & 48 \\
\hline
\end{tabular}

Source: survey data (2016).

Table 6. Category of work ability in relation to average time in job position.

\begin{tabular}{lccc}
\hline \multicolumn{1}{c}{ Work ability } & $\boldsymbol{N}$ & Average & Homogeneous Group \\
\hline EXCELLENT & 29 & 6.42 & 1 \\
GOOD & 15 & 12.87 & 2 \\
MODERATE & 6 & 12.15 & 3 \\
LOW & 1 & 40.00 & 3 \\
\hline
\end{tabular}

Source: survey data (2016). 


\subsection{Sociodemographic profile and work ability}

The average height of the workers was $1.71 \mathrm{~m}$ $(\mathrm{s}=0.07)$ and the average weight was $72.48 \mathrm{~kg}$ $(\mathrm{s}=16.39)$, resulting in an average Body Mass Index - BMI of $24.67 \mathrm{~kg} / \mathrm{m}^{2}(\mathrm{~s}=5.36)$. There was no statistical significance between BMI and WAI using the Kruskal-Wallis test ( $\mathrm{p}>0.05)$.

As for civil status, $35.29 \%$ were unmarried; $58.82 \%$ were married or living with partners; and $5.88 \%$ were separated or divorced. This was one of the factors where statistical significance was found between the groups, being $p<0.05$. It was possible to verify that 3 workers with "separated" marital status had a mean WAI of $35, \mathrm{~s}=8.544$, whose index characterized them in the moderate classification, as shown in Table 7. However, it is important to observe the coefficient of variation of the workers in the "separated" group, since it demonstrates that both good and low work ability are possible.

The group of "married" workers presented an average of 41.12 and $s=4.70$. This result indicates that the classification of this group can range from moderate to excellent work ability. Finally, single workers, $\mathrm{M}=43.95$ and $\mathrm{s}=2.77$, presented lower variation, ranging from good to excellent work ability.

One of the factors that revealed a negative influence on WAI was civil status. Workers who declare themselves to be separated or divorced presented lower average WAI. This group of workers does not present linearity in the behavior of the WAI, possibly because the social condition of their relationship influences the work ability. "Separate" civil status presents evidence that there is influence on well-being or personal condition. This was not observed in the grouping of "single" or "married/living with partner" workers, who presented linearity in the behavior of the WAI.

Of those interviewed, $49.02 \%$ reported not having or being responsible for children, while $50.98 \%$ declared yes $(p>0.05)$. The data collected also revealed that $7.84 \%$ are responsible for people with special needs ( $>0.05$ ), and $19.61 \%$ are responsible for the elderly $(p>0.05)$. None of these factors represented statistical significance with the WAI, at a $95 \%$ confidence level.

About $50 \%$ of those interviewed said they had children or were responsible for some children.
This factor did not statistically influence the WAI. Previous studies have pointed out that the role of caring for children may be a factor influencing WAI, especially in the case of women (Vasconcelos et al., 2011; Vedovato \& Monteiro, 2014). In the present case, where the population was predominantly male, no relationship was found between these factors.

As for income, $25.49 \%$ declared family income of up to 2 minimum wages (MW); 58.82\% reported family income of 2 to $4 \mathrm{MW} ; 11.76 \%$ from 4 to $6 \mathrm{MW}$; and $3.92 \%$ above $6 \mathrm{MW}$. Regarding the family's livelihood, $58.82 \%$ are the main individual responsible for their household income. Of the interviewees, $7.84 \%$ have another job. Using the nonparametric Kruskal-Wallis test, these factors did not represent statistical significance with the WAI ( $p>0.05$ ).

One of the factors that is pointed out in the literature as capable of promoting the work ability is the improvement of the economic situation (Tuomi et al., 2004). In this economic field, it is important to highlight that better financial conditions can provide the worker with a more comfortable social situation, so that concerns about the lack of resources to support the family do not exist. Thus, professional valuation can be highlighted as a positive factor to be observed by companies.

The responsibility of providing the family's main income and working another job has already been negatively associated with WAI (Fischer et al., 2006; Vasconcelos et al., 2011). Although studies have demonstrated this, in the study with furniture workers there was no influence.

Most of the interviewees do not study (84.31\%), $37.75 \%$ only attended elementary school, $45.10 \%$ went to high school, $13.73 \%$ have a college education and $3.92 \%$ have a graduate degree. When investigating the influence of these factors on the dependent variable, WAI, statistical significance was found for "currently studying" and "education" being $p<0.05$. These data are shown in Table 8.

In observing the minimum and maximum indices obtained, it is possible to affirm that the workers who currently study vary in the range of good or excellent work ability. Those who do not study vary from low to excellent capacity (WAI 26 to 48). In the field of development and personal training, the literature points out that the opportunity to develop their

Table 7. Classification of WAI according to civil status.

\begin{tabular}{lcccccc}
\hline \multicolumn{1}{c}{ Civil Status } & N & Average & Median & $\begin{array}{r}\text { Standard } \\
\text { Deviation }\end{array}$ & $\begin{array}{r}\text { Coefficient of } \\
\text { Variation \% }\end{array}$ & $\begin{array}{c}\text { WAI } \\
\text { Classification }\end{array}$ \\
\hline Separated & 3 & 35.0 & 36.0 & 8.54 & 24.41 & Moderate \\
Married or living with partner & 29 & 41.1 & 42.0 & 4.70 & 11.43 & Good \\
Single & 19 & 43.9 & 44.0 & 2.77 & 6.31 & Good \\
Total & $\mathbf{5 1}$ & $\mathbf{4 1 . 8}$ & $\mathbf{4 3 . 0}$ & $\mathbf{4 . 7 8}$ & $\mathbf{1 1 . 4 3}$ & Good \\
\hline
\end{tabular}

Source: survey data (2016). 
Table 8. WAI analysis from workers that are currently studying.

\begin{tabular}{|c|c|c|c|c|c|c|}
\hline & $N$ & Average & $\begin{array}{l}\text { Standard } \\
\text { Deviation }\end{array}$ & $\begin{array}{c}\text { Coef. of } \\
\text { Variation \% }\end{array}$ & Minimum & Maximum \\
\hline \multicolumn{7}{|c|}{ Do you currently study? } \\
\hline No & 43 & 41.20 & 4.86 & 11.80 & 26 & 48 \\
\hline Yes & 8 & 45.12 & 2.57 & 5.70 & 40 & 48 \\
\hline Total & 51 & 41.81 & 4.78 & 11.43 & 26 & 48 \\
\hline \multicolumn{7}{|l|}{ Current education } \\
\hline Elementary School & 19 & 41.55 & 4.77 & 11.49 & 29 & 47 \\
\hline High School & 23 & 41.61 & 4.77 & 11.47 & 26 & 48 \\
\hline College Education & 7 & 45.21 & 2.74 & 6.05 & 40 & 48 \\
\hline Graduate Education & 2 & 34.75 & 1.77 & 5.09 & 33 & 36 \\
\hline Total & 51 & 41.81 & 4.78 & 11.43 & 26 & 48 \\
\hline
\end{tabular}

Source: survey data (2016).

skills and abilities should be stimulated, as a factor contributing to the improvement of work ability (Tuomi et al., 2001).

In the case of educational level, it was found that graduate workers had a lower WAI average, with a classification ranging from moderate to good work ability. This phenomenon may be an isolated fact of these two workers, and it is necessary to evaluate a greater number of cases in future studies. Another fact that can be associated is the underutilization of the ability and potential of the workers. The fact of having specialized education and working in small companies can be an indication that the worker feels underutilized. Thus, in the cases under analysis, it is verified that in one case, the presence of diseases contributed to a lower ability, and, in both cases, the workers considered themselves less able to work. Also, it is noted that one of these workers has a medical diagnosis of mild emotional disturbance (e.g. mild depression, tension, anxiety, insomnia) and the other said to be totally unable to work.

On the other hand, workers with "elementary school" and "high school" level of education presented a higher degree of variation, with workers with low to excellent work ability. As for workers with "college education", the work ability oscillated between good and excellent.

The relationship between the WAI and the level of schooling was also investigated, including whether the worker studies or not. Statistical significance was found in both cases. The workers who currently study had a higher average WAI, and a coefficient of variation of only $5.70 \%$. This result is in agreement with studies that point out that higher schooling positively influences work ability (Chan et al., 2000; Martinez $\&$ Latorre, 2006). However, the level of schooling in the case in question showed that 2 graduate workers ranged from moderate to good ability, resulting in a different result from the existing literature.

\subsection{Social habits and work ability}

When investigating the practice of sports, $52.94 \%$ stated they did not perform activities, and $47.06 \%$ did. This variable did not present significance with the WAI $(p>0.05)$. The practice of physical activities presented statistical significance in relation to mental resources (construct 7, p <0.05). The group of workers who did not practice physical activity had a slightly lower average of mental resources ( $M=3.67)$, compared to those who practiced physical activities $(M=3.92)$. The practice of physical exercises outside of the work environment is one of the factors that promotes the work ability (Tuomi et al., 2004, Ilmarinen, 2002; Chiu et al., 2007). About $50 \%$ of the sample reported practicing physical activities, however, with no statistical relation to the results. Even in the face of this reality, it is important to encourage the practice of sports or physical activities in order to improve the quality of life for the worker and their well-being.

The workers also reported that $68.63 \%$ performed household tasks, whose variance was not associated with the WAI ( $p>0.05)$. The literature has found that there is a lower work ability with women who perform domestic tasks, given the role of women in organizing and caring for the home (Monteiro \& Fernandes, 2006). In the case under analysis, with a predominantly male population, this factor did not influence.

Regarding smoking, $78.42 \%$ never smoked, $11.76 \%$ were ex-smokers, and $9.8 \%$ smoked. Regarding the ingestion of alcoholic beverages, $43.14 \%$ did not drink and $56.86 \%$ reported drinking at least once a week. In both cases there was no statistical significance, being $p>0.05$. These results are in agreement with previous studies (Tuomi et al., 2004; El Fassi et al., 2013; Sampaio et al., 2009). This may mean the so-called "healthy worker" effect (Monteiro \& Fernandes, 2006), based on the hypothesis that workers with alcoholism or smoking problems are not hired by companies, may be due to workers being away 
from work at the time of the research, or because they did not participate in the survey.

Among the leisure activities cited by the interviewees were: watching TV, movies or going to the movies $68 \%$; playing sports $48 \%$; travel $28 \%$; activities with music and arts $18 \%$; reading books $14 \%$; participating in organizations or performing voluntary services $14 \%$; while $10 \%$ declare that they do not have leisure time. Again, there was no statistical significance between the leisure factor and the WAI dependent variable ( $p>0.05)$. It is noted that the study population - carpenters - has a high number of workers with better work ability. Although there is no statistical significance between the factors, it is important to highlight that the leisure practice contributes to a better quality of life as well as a better well-being of the worker.

\subsection{Promoting work ability}

It was verified that 7 workers presented low (1) or moderate (6) work ability. For these workers, the restoration of their work ability must be sought. Martinez et al. (2010) present the determinants that can influence, positively or negatively, the work ability: lifestyle, health, education and skills, and work.

Lifestyle habits such as smoking, excessive alcohol consumption and obesity negatively influence the individual's work ability. Although this study did not find significance among these indicators, it is recommended that companies be aware of these habits and promote guiding actions to teach about the harm that can be cause to health. On the other hand, the practice of physical exercises, usually associated with good work ability, can be stimulated.

The general health of the worker, in all aspects, is also tied to his productive ability, being indicated as the factor that exerts the greatest impact on the index (Martinez et al., 2010). In the case of carpenters, where there are several unhealthy factors, management of the company should be even more careful with the health of the worker.

The work ability can also be promoted by programs to encourage education and the development of skills (Martinez et al., 2010).

Conditions in the workplace can also be improved. In carpentry, where there is a high level of physical demand, actions of ergonomic improvements in order to prevent diseases and above all to improve working conditions in the industry can be taken. Studies have pointed out that the presence of physical overload is detrimental to the worker's ability (Huuhtanen et al., 1997; Paula et al., 2015).

Still other measures can be taken to improve the work ability. Tuomi et. al (2005), list a series of recommendations, based on three approaches: 1 - reducing the workload and improving the working environment (ergonomics, occupational hygiene, safety); 2 - improving the work group and work organization (personal relations, collaboration, management); 3 - improving functional capacity (physical activity, healthy and invigorating lifestyles) and promoting professional skills.

These measures are not exhausted here, since the company can find several mechanisms to promote work ability. The practical contribution that is presented in this study is to recommend that carpentry companies, given the reality that their employees generally present good work ability, can include measures in their actions aimed at maintaining this adequate level. In particular, with older workers, it is necessary to turn attention to them so that this demographic is assisted with the actions necessary to restore or maintain the work ability.

Theoretically, this research contributes in the sense that no studies with this theme were found on carpentry workers in this region of the country. Also, it is highlighted the finding that with the advancement age, carpenters also present a reduction of work ability.

\section{Conclusions}

The study of small companies is important, since in Brazil, more than $40 \%$ of the jobs generated are in micro and small companies. The field of carpentry plays a prominent role in the economy of the state of Santa Catarina, which is why the relevance of studies in this area is highlighted.

Carpentry workers who participated in this survey revealed good indices of work ability. It was noted that there were few cases of low indices, which should be a reason for attention. For these workers, companies must promote actions to restore or improve the work ability. On the other hand, since the majority of the population had better indices, companies should likewise look at these workers, utilizing this labor potential of the human capital they have. Thus, actions that improve and promote the work ability are indispensable to maintain the good indices presented by the workers.

\section{References}

Amorim, J. S., Salla, S., \& Trelha, C. S. (2014). Factors associated with work ability in the elderly: systematic review. Revista Brasileira de Epidemiologia, 17(4), 830841. http://dx.doi.org/10.1590/1809-4503201400040003. PMid:25388484.

Brasil. Ministério do Desenvolvimento Indústria e Comércio Exterior - MDIC. (2016). Cadeia produtiva de madeira. Retrieved in 2016, April 23, from http://www.mdic. gov.br/sitio/interna/interna.php?area $=2 \&$ menu $=317$

Chan, G., Tan, V., \& Koh, D. (2000). Ageing and fitness to work. Occupational Medicine, 50(7), 483-491. http:// dx.doi.org/10.1093/occmed/50.7.483. PMid:11198672. 
Chiu, M.-C., Wang, M.-J. J., Lu, C.-W., Pan, S.-M., Kumashiro, M., \& Ilmarinen, J. (2007). Evaluating work ability and quality of life for clinical nurses in Taiwan. Nursing Outlook, 55(6), 318-326. http://dx.doi. org/10.1016/j.outlook.2007.07.002. PMid:18061017.

El Fassi, M., Bocquet, V., Majery, N., Lair, M. L., Couffignal, S., \& Mairiaux, P. (2013). Work ability assessment in a worker population: comparison and determinants of Work Ability Index and Work Ability score. BMC Public Health, 13(1), 10. http://dx.doi.org/10.1186/1471-245813-305. PMid:23565883.

Federaçao das industrias do estado de Santa Catarina - FIESC. (2015). Santa Catarina em dados - 2015. Retrieved in 2016, April 23, from http://fiesc.com.br/ sites/default/files/medias/sc_em_dados_site_correto.pdf

Fiedler, N. C., Venturoli, F., Minetti, L. J., \& Vale, A. T. (2001). Diagnóstico de fatores humanos e condições de trabalho em marcenarias no distrito federal. Revista Floresta, 31(12), 1-9.

Fischer, F. M., Borges, N. D., Rotenberg, L., Latorre, M. D., Soares, N. S., Rosa, P. L., \& Landsbergis, P. (2005). A (in) capacidade para o trabalho em trabalhadores de enfermagem. Revista Brasileira de Medicina do Trabalho, 3(2), 97-103.

Fischer, F. M., Borges, F. N., Rotenberg, L., Latorre, M., Soares, N. S., Rosa, P. L., \& Landsbergi, P. (2006). Work ability of health care shift workers: what matters? Chronobiology International, 23(6), 1165-1179. http:// dx.doi.org/10.1080/07420520601065083. PMid:17190703.

Freitas, H., Oliveira, M., Saccol, A. Z., \& Mascarola, J. (2000). O método de pesquisa Survey. Revista ADM, 35(3), 105-112.

Huuhtanen, P., Nygård, C. H., Tuomi, K., \& Martikainen, R. (1997). Changes in stress symptoms and their relationship to changes at work in 1981-1992 among elderly workers in municipal occupations. Scandinavian Journal of Work, Environment \& Health, 23(1, Suppl 1), 36-48. PMid:9247994.

Ilmarinen, J., Tuomi, K., \& Klockars, M. (1997). Changes in the work ability of active employees over an 11-year period. Scandinavian Journal of Work, Environment \& Health, 23(1, Suppl 1), 49-57. PMid:9247995.

Ilmarinen, J. (2002). Physical requirements associated with the work of aging workers in the European Union. Experimental Aging Research, 28(1), 7-23. http://dx.doi. org/10.1080/036107302753365513. PMid:11928212.

Ilmarinen, J. (2009). Work ability-a comprehensive concept for occupational health research and prevention. Scandinavian Journal of Work, Environment \& Health, 35(1), 1-5. http://dx.doi.org/10.5271/sjweh.1304. PMid:19277432.

Klasan, A., Madzarac, G., Milosevic, M., Mustajbegovic, J., \& Keleuva, S. (2013). Predictors of lower work ability among emergency medicine employees: the Croatian experience. Emergency Medicine Journal, 30(4), 275 279. http://dx.doi.org/10.1136/emermed-2011-200780. PMid:22573906.
Koolhaas, W., van der Klink, J. J., de Boer, M. R., Groothoff, J. W., \& Brouwer, S. (2014). Chronic health conditions and work ability in the ageing workforce: the impact of work conditions, psychosocial factors and perceived health. International Archives of Occupational and Environmental Health, 87(4), 433-443. PMid:23677519.

Kumashiro, M. (2014). An approach of ergonomics and management in occupational health for a society of aging workers. Journal of Japan Industrial Management Association, 65(2), 124-130.

Larsson, A., Karlqvist, L., Westerberg, M., \& Gard, G. (2012). Identifying work ability promoting factors for home care aides and assistant nurses. BMC Musculoskeletal Disorders, 13(1), 1-11. http://dx.doi.org/10.1186/14712474-13-1. PMid:22236253.

Martinez, M. C., \& Latorre, M. R. (2006). Health and work ability among office workers. Revista de Saude Publica, 40(5), 851-858. http://dx.doi.org/10.1590/ S0034-89102006000600015. PMid:17301907.

Martinez, M. C., \& Latorre, M. R. D. O. (2008). Health and work ability of workers of the electricity sector in Sao Paulo. Ciencia \& Saude Coletiva, 13(3), 1061-1073. http://dx.doi.org/10.1590/S1413-81232008000300029. PMid:18813600.

Martinez, M. C., Latorre, M., \& Fischer, F. M. (2009). Validity and reliability of the Brazilian version of the Work Ability Index questionnaire. Revista de Saude Publica, 43(3), 7. PMid:19347177.

Martinez, M. C., Latorre, M., \& Fischer, F. M. (2010). Capacidade para o trabalho: revisão de literatura. Ciencia \& Saude Coletiva, 15(1, Suppl 1), 1553-1561. http://dx.doi.org/10.1590/S1413-81232010000700067. PMid:20640317.

Monteiro, M. I., \& Fernandes, A. C. (2006). Capacidade para o trabalho de trabalhadores de empresa de tecnologia da informação. Revista Brasileira de Enfermagem, 59(5), 603-608. http://dx.doi.org/10.1590/S003471672006000500002 . PMid:17340701.

Monteiro, M. S., Ilmarinen, J., \& Gomes, J. (2005). Capacidade para o trabalho, saúde e ausência por doença de trabalhadoras de um centro de pesquisa por grupos de idade. Revista Brasileira de Saúde Ocupacional, 30(112), 81-90. http://dx.doi.org/10.1590/S030376572005000200008 .

Padula, R. S., Comper, M. L., Moraes, S. A., Sabbagh, C., Pagliato, W., Jr., \& Perracini, M. R. (2013). The work ability index and functional capacity among older workers. Brazilian Journal of Physical Therapy, 17, 382-391.

Paula, Í. R., Marcacine, P. R., Castro, S. S., \& Walsh, I. A. (2015). Capacidade para o trabalho, sintomas osteomusculares e qualidade de vida entre agentes comunitários de saúde em Uberaba, Minas Gerais. Saúde e Sociedade, 24(1), 152-164. http://dx.doi.org/10.1590/ S0104-12902015000100012.

Saltychev, M., Laimi, K., Oksanen, T., Pentti, J., Kivimäki, M., \& Vahtera, J. (2013). Does perceived work ability improve after a multidisciplinary 
preventive program in a population with no severe medical problems? The Finnish Public Sector Study. Scandinavian Journal of Work, Environment \& Health, 39(1), 57-65. http://dx.doi.org/10.5271/ sjweh.3298. PMid:22508527.

Sampaio, R. F., Coelho, C. M., Barbosa, F. B., Mancini, M. C., \& Parreira, V. F. (2009). Work ability and stress in a bus transportation company in Belo Horizonte, Brazil. Ciencia \& Saude Coletiva, 14(1), 287-296. http://dx.doi.org/10.1590/S1413-81232009000100035. PMid:19142333.

Silva, K. R., Souza, A. P., \& Minetti, L. J. (2002). Avaliação do perfil de trabalhadores e das condições de trabalho em marcenarias no município de Viçosa-MG. Revista Árvore, 26(6), 769-775. http://dx.doi.org/10.1590/ S0100-67622002000600013.

Tuomi, K., Huuhtanen, P., Nykyri, E., \& Ilmarinen, J. (2001). Promotion of work ability, the quality of work and retirement. Occupational Medicine, 51(5), 318-324. http://dx.doi.org/10.1093/occmed/51.5.318. PMid:11473138.

Tuomi, K., Ilmarinen, J., Jahkola, A., Katajarinne, L., \& Tulkki, A. (2005). Índice de capacidade para o trabalho (F. M. Fischer, Trad.). São Carlos: EDUFSCAR.
Tuomi, K., Ilmarinen, J., Martikainen, R., Aalto, L., \& Klockars, M. (1997). Aging, work, life-style and work ability among Finnish municipal workers in 1981-1992. Scandinavian Journal of Work, Environment \& Health, 23(1, Suppl 1), 58-65. PMid:9247996.

Tuomi, K., Vanhala, S., Nykyri, E., \& Janhonen, M. (2004). Organizational practices, work demands and the well-being of employees: a follow-up study in the metal industry and retail trade. Occupational MedicineOxford, 54(2), 115-121. http://dx.doi.org/10.1093/ occmed/kqh005. PMid:15020730.

Vasconcelos, S. P., Fischer, F. M., Reis, A. O. A., \& Moreno, C. R. C. (2011). Factors associated with work ability and perception of fatigue among nursing personnel from Amazonia. Revista Brasileira de Epidemiologia, 14(4), 688-697. http://dx.doi.org/10.1590/S1415790X2011000400015. PMid:22218667.

Vedovato, T. G., \& Monteiro, I. (2014). Health conditions and factors related to the work ability of teachers. Industrial Health, 52(2), 121-128. http://dx.doi.org/10.2486/ indhealth.2013-0096. PMid:24429517.

World Health Organization - WHO. (2015). Ageing and health. Retrieved in 2016, January 16, from http://www. who.int/mediacentre/factsheets/fs404/en/\# 